\title{
Staying Safe in a Tornado: A Qualitative Inquiry into Public Knowledge, Access, and Response to Tornado Warnings
}

\author{
JAYME E. WALTERS AND LiSA REYES MASON \\ College of Social Work, University of Tennessee, Knoxville, Tennessee \\ KELSEY ELLIS \\ Department of Geography, University of Tennessee, Knoxville, Tennessee \\ BETSY WINCHESTER \\ College of Social Work, University of Tennessee, Knoxville, Tennessee
}

(Manuscript received 5 May 2019, in final form 5 November 2019)

\begin{abstract}
Tornadoes in the southeastern United States continue to cause substantial injury, death, and destruction. The present study seeks to 1) understand inadequate warning access, less understanding, and/or less likelihood of responding to tornado warnings; 2) examine public attitudes about NWS communications; and 3) explore the perceptions of NWS personnel regarding public response to tornado warnings, factors that might influence response, and how their perceptions impact their communication. Participants include a purposive sample of NWS forecasters in Tennessee $(n=11)$ and residents $(n=45)$ who were identified as having low access to, low knowledge of, or an unsafe response to tornado warnings in a previous study. A qualitative approach with semistructured interviews was used. Findings indicated that most participants had at least one warning source. Barriers to warning access included electricity outages, rurality, lack of storm radio, heavy sleeping, and hearing impairments. Most participants had knowledge of NWS guidelines for safe shelter seeking but still engaged in behaviors considered unsafe. Proximity, personal experience, and influence of family and friends emerged as influencers of response to warnings. NWS personnel perceived that proximity played a significant role in shelter-seeking behavior as well as the need for confirmation. Poor access to safe shelter arose as a major concern for NWS personnel, specifically mobile home residents. Messaging and specificity in warnings to evoke safe shelter-seeking behavior surfaced as critical issues for NWS personnel. Implications for education and policy changes to enhance public safety and improve public health are noted.
\end{abstract}

\section{Introduction}

Taking the lives of 23 people and injuring nearly 100 more, the EF4 tornado in Lee County, Alabama, on 3 March 2019 is a grim reminder of the destruction that natural hazards can cause (NOAA/NWS 2019c). Unfortunately, devastating tornadoes are prevalent in the Southeast region of the United States, which has the most EF2 or larger events and deadly tornadoes in the world (Ingram et al. 2013). With increased prevalence of these hazards, safe shelter-seeking behavior among Southeastern residents is critical. Yet, past research indicates that many individuals are making risky —and sometimes, life-altering-choices when faced with a

Corresponding author: Jayme E. Walters, jwalte22@tennessee.edu tornado (e.g., Balluz et al. 2000; Chaney and Weaver 2010; Chiu et al. 2013; Liu et al. 1996; NOAA/NWS 2011a; Sherman-Morris 2010).

Knowledge about tornado warnings (e.g., Liu et al. 1996) and access to warnings (e.g., Miran et al. 2018), along with demographical, sociological, and cognitive characteristics have been identified in quantitative research as predictors of public response to tornado warnings and susceptibility to tornado-related injury or fatality (e.g., Cong et al. 2014; Schmidlin et al. 2008; Walters et al. 2019). However, in a recent study, researchers found that NWS forecasters do not have a clear understanding of the reasons behind people not seeking shelter and rate this as a high priority for future research (Sherman-Morris et al. 2018). Other research areas that forecasters deemed important included the 
information that users desire in warnings and "how well people understand warnings, what actions they take upon receiving a warning, and how to best communicate uncertainty" (Sherman-Morris et al. 2018, p. 607). Because a great deal of responsibility to communicate tornado warning and safety information rests on NWS forecasters, having knowledge and understanding about these topics is essential to reduce injuries and fatalities caused by tornadoes.

The present study is part of a larger study funded by NOAA as part of its Verification of the Origins of Rotation in Tornadoes Experiment-Southeast (VORTEX-SE) initiative, which has the overarching goal of reducing harm to the public from tornadoes (Rasmussen 2015). In addition to seeking new knowledge about atmospheric conditions surrounding tornadic storms in the Southeast, VORTEXSE also incorporates societal-impact topics including lead time, false alarms, nocturnal events, shelters, sirens, television communications, changes in communication and planning for high fatality events, and complacency (Rasmussen 2015). The Southeast has the highest fatality and injury rates in the United States due to tornadoes, likely due to physical and social vulnerabilities (Ashley 2007; Fricker et al. 2017). While being home to the strongest tornadoes (events EF2-EF5; Coleman and Dixon 2014), the Southeast also has the most nocturnal tornadoes in the United States, which are more likely to have a fatality than daytime tornadoes (Ashley et al. 2008). Further, the Southeast has a larger portion of mobile home dwellers compared to other regions of the United States, and due to the instability of mobile homes, residents of these structures make up for approximately $44 \%$ of tornado fatalities (Ashley 2007).

Using Tennessee as a case example, qualitative methods are employed to achieve three objectives. First, the study seeks to understand why some individuals have inadequate warning access, less understanding, and/or less likelihood of responding to tornado warnings in potentially harm-reducing or life-saving ways. Second, the study examines public attitudes and opinions about NWS communications and how these could improve. Finally, the study explores the perceptions of NWS personnel regarding the public's behavioral response to tornado warnings, factors that might influence public response, and how their own perceptions of the public's response impact NWS warning communications. The qualitative approach in this study provides rich insights into why portions of the public do not receive warnings, their understanding and use of warnings, and their reasons behind not seeking shelter upon receiving a warning, which are critical knowledge gaps for NWS personnel according to Sherman-Morris et al. (2018). Additionally, few studies consider NWS personnel perspectives regarding public access and response to tornado warnings and how these attitudes might influence their communication with the public. Attitudes can influence actions (Ajzen and Fishbein 2005), and thus, NWS communication with the public (i.e., actions) might be impacted by personal attitudes rather than actual reasons that the public responds or not to tornado warnings. Summarizing a 2012 workshop called, Weather Ready Nation: Science Imperatives for Severe Thunderstorm Research, Lindell and Brooks (2013) indicate a research need related to forecasters themselves: “. . .behavioral research on forecasters' judgment and decision processes and the ways these processes differ across individuals and NWS regions" (p. 2). Delving into NWS personnel perspectives and comparing them with insights from the public can identify disparities between NWS's approach to issuing tornado warnings and the public's access, knowledge, and use of tornado warnings. Pinpointing discrepancies as well as identifying strengths can help NWS be better informed and hone their messages and programming as needed.

\section{Background}

\section{a. Conceptual framework}

Between 1950 and 2017, tornadoes in the United States have taken the lives of 6912 people and injured over 108000 people (NOAA/SPC 2018a). Recently, Agee and Taylor (2019) conducted a historical analysis of tornado fatalities by dividing records into two eras, 1808-1915 and 1916-2017. Using death per population index (DPI) to examine 21 states within the Great Plains, Southeast, and adjacent Midwestern states, they found that fatalities due to tornadoes decreased in the most recent era (1916-2017), likely because of advances in science and technology (Agee and Taylor 2019). However, tornadoes can wreak havoc on communities as evidenced in recent NWS service assessments of tornadic events (e.g., NOAA/NWS 2011a,b) and other NWS data (e.g., NOAA/SPC 2018b). Devasting events such as the 2011 Joplin tornado that killed 160 people and injured 1600 others (Paul et al. 2015) serve as continued motivation to determine and use effective approaches to address this public health threat.

Understanding the public's perception of risk, decisionmaking, and factors that impact these constructs are critical. Mileti and Sorensen (1990) describe a sequential, social-psychological process that occurs when a person is confronted with a tornado warning. Stages that an individual might pass through upon receiving a tornado warning include hearing, understanding, believing, personalizing, deciding and responding, and confirming (Mileti and Sorensen 1990; see Table 1). Due to the 
TABLE 1. The individual social-psychological process upon tornado warning receipt (Mileti and Sorensen 1990). Provided is a summary of each stage in the social-psychological process that an individual might traverse through when receiving a tornado warning (Mileti and Sorensen 1990).

\begin{tabular}{lc}
\hline \hline \multicolumn{1}{c}{ Stage } & \multicolumn{1}{c}{ Meaning } \\
\hline Hearing & $\begin{array}{c}\text { The person receives a tornado warning } \\
\text { notification. } \\
\text { The person attaches meaning to the } \\
\text { tornado warning notification. } \\
\text { The person decides authenticity and } \\
\text { accuracy of the tornado warning } \\
\text { netification. }\end{array}$ \\
The person determines how the \\
personalizing & $\begin{array}{c}\text { potential tornado threat may impact } \\
\text { them and their social network. } \\
\text { The person chooses the action(s) to take } \\
\text { based on prior stages. } \\
\text { The person solicits further information } \\
\text { Confirming }\end{array}$ \\
& $\begin{array}{c}\text { about the tornado threat to validate } \\
\text { decision(s). }\end{array}$ \\
\hline
\end{tabular}

impact of internal and external factors, the process is unique for each person, meaning that some people will pass through some stages while others will enter all stages, and the length of time spent in each stage will also differ (Mileti and Sorensen 1990). A comprehensive framework, the Protective Action Decision Model (PADM) as presented by Lindell and Perry (2012), organizes variables that prompt decision-making, and thus a behavioral response, when faced with environmental hazards. The factors potentially influencing an individual's risk perception and decision-making process are environmental cues, social cues, information sources, channel access and preference, warning messages, and receiver characteristics (Lindell and Perry 2012 , p. 617). These factors are the subject of much previous research to understand people's behavioral response to warnings (i.e., to seek shelter or not) as discussed in the proceeding sections.

\section{b. Access to and preference of information sources}

NWS reaches the public with tornado warnings, directly and indirectly. Individuals may access information from NWS online (i.e., website and social media) or NOAA weather radios. Indirect sources of warning distribution are television and radio outlets, local emergency managers, and other weather providers (Brotzge and Donner 2013). Television continues to be the leading method by which people receive warnings (e.g., Jauernic and Van Den Broeke 2016; Mason et al. 2018).

Even in an age of readily available information, concern still exists that individuals are not receiving tornado warnings. Of particular concern are individuals who are not native English speakers and those not from a country where tornadoes are common-these individuals may not know how to get information from appropriate sources or understand warnings even if received (Ahlborn and Franc 2012; Burke et al. 2012; Donner et al. 2012; Senkbeil et al. 2012). Additionally, people may be particularly vulnerable at night. In a study comparing warning receipt in the day versus night, most people had a high chance of receiving a warning if issued during the day; whereas at night, less than half had a high likelihood of receiving the warning (Mason et al. 2018). With Tennessee experiencing more than $45 \%$ of its tornadoes at night (Ashley et al. 2008), residents receiving proper notification of a tornado between dusk and dawn is a concern.

Previous research shows that most people receive warnings from more than one source, and those who receive multiple warnings are more likely to engage in safe shelter-seeking behaviors (Hammer and Schmidlin 2002; Luo et al. 2015; Miran et al. 2018; Paul et al. 2015). Regarding warning sources, the public still relies heavily on traditional sources like television and radio reports, sirens, and phone calls to receive warnings (e.g., Durage et al. 2014; Jauernic and Van Den Broeke 2016; Mason et al. 2018). With $95 \%$ of the U.S. adult population having a mobile connection and $75 \%$ with smartphones (Pew Research Center 2018), cell phone alerts are increasingly used to get severe weather notifications, and many people prefer them because the information arrives automatically via their mobile carriers if they participate in the Wireless Emergency Alerts (WEA) system (e.g., Durage et al. 2014; Mason et al. 2018; Silver 2015). In 2012, the Federal Communications Commission (FCC) created the WEA system that enables mobile carriers to send electronic messages to cell phones for emergency situations including inclement weather (Federal Communications Commission 2018).

Notifications to or from family and friends also help keep people informed and safe (e.g., Afifi et al. 2014; Donner et al. 2012; Burke et al. 2012; Durage et al. 2014; Mason et al. 2018; Walters et al. 2019). Some studies have indicated that using environmental cues-going outside to look at the clouds, for example-is a common practice, albeit a potentially dangerous one (e.g., Durage et al. 2014; Paul et al. 2015). Use of social media has not yet risen to the levels of other sources while NOAA radios are being used minimally (e.g., Hammer and Schmidlin 2002; Durage et al. 2014; Mason et al. 2018; Silver 2015).

For warning alerts, past studies have shown that individuals desire specific geographic details-cities and landmarks nearby, direction of travel, and seriousness 
of the situation-to inform their decision about seeking shelter (Donner et al. 2012; Jauernic and Van Den Broeke 2016; Ripberger et al. 2015). While the type of information included in the warning is critical, trust in the forecast and the meteorologist or weathercaster delivering the messages are also important when internalizing the risk of harm and whether to take protective actions (Brotzge and Donner 2013; Losee and Joslyn 2018; Sherman-Morris 2005). False alarms, or situations when a tornado warning was issued but one did not occur (NOAA/NWS 2011c), have been associated with trust and thereby shelter-seeking behavior: Simmons and Sutter (2009) “... found strong evidence that a higher local, recent FAR [false alarm rates] significantly increases tornado fatalities and injuries..." (p. 52). Another study found that many people characterized false alarms as dishonest or misguided by forecasters, which creates problematic relationships between the public and weather informants (Trainor et al. 2015).

\section{c. Receiver knowledge and understanding of tornadoes}

Many people in areas prone to tornadoes have received education about severe weather and safety (e.g., Chaney et al. 2013), though the knowledge sources are less known. Past research has shown that most people have general knowledge about tornadoes, specifically watches and warnings (e.g., Balluz et al. 2000; Donner et al. 2012; Jauernic and Van Den Broeke 2016; Silver 2015). Individuals often take an interest in their local weather patterns and become familiar with their area by watching environmental cues (Klockow et al. 2014; Silver 2015). However, there are pockets of the population who still do not know basic concepts (e.g., Ash 2017; Donner et al. 2012). Lack of knowledge can be detrimental as it has been associated with not seeking safe shelter (e.g., Jauernic and Van Den Broeke 2016; Ripberger et al. 2015). Beyond the basics, individuals are often confused or misled by myths or false information about tornado behavior, potentially leading to unsafe responses. Inaccurate beliefs exist that terrain-like hills, rivers, mountains, and snow-covered grounds-as well as tall buildings impact tornadoes' behavior or provide protection to residents (e.g., Donner et al. 2012; Jauernic and Van Den Broeke 2017; Klockow et al. 2014; Ripberger et al. 2015; Van Den Broeke and Arthurs 2015).

\section{d. Other receiver characteristics}

Previous studies have provided a wealth of information regarding factors associated with warning response, both safe and unsafe. Many factors are related to demographic and sociological characteristics as well as beliefs and experiences (or, cognitive factors). Past studies have found that men do not heed warnings as closely as women (Sherman-Morris 2010; Silver and Andrey 2014), though other studies have found no association with gender and response (e.g., Miran et al. 2018; Nagele and Trainor 2012). Age, too, has mixed results; depending on the study, older or younger people are found to be more prepared (e.g., Senkbeil et al.2012; Chaney et al. 2013), yet other inquiries have found no relationship between age and response (e.g., Durage et al. 2014; Miran et al. 2018). As noted previously, ethnicity and native language affect ability to receive and understand warnings and thus take shelter (e.g., Ahlborn and Franc 2012; Burke et al. 2012). While Caucasian individuals have been found more likely to plan for tornadoes and seek shelter than people of other races (Cong et al. 2014; Luo et al. 2015), a recent study found that African Americans had a higher chance of finding out about warnings during the day than Caucasian participants (Mason et al. 2018). Some studies have found that people with increased levels of education and income are more prepared and likely to receive warnings and heed them (e.g., Brotzge and Donner 2013; Liu et al. 1996; Mason et al. 2018; Senkbeil et al. 2012). Young children residing in households have been linked to planning for and reacting appropriately to tornadoes (e.g., Chaney et al. 2013). Residents' proximities to tornadoes also make a difference in engaging in protective action; one study found that if the tornado was more than five miles away, participants did not take cover (Nagele and Trainor 2012). The role of fatalism - the idea that one has very little control over their fate-has been associated with reduced shelterseeking behavior as well (e.g., Schmidlin et al. 2008; Senkbeil et al. 2012; Walters et al. 2019).

Past experience with tornadoes and likelihood to take shelter has been examined in-depth, and yet, results are inconclusive. Some studies indicate that if a person has been in a tornado, they are more likely to react appropriately (e.g., Comstock and Mallonee 2005; BlachardBoehm and Cook 2004), but other researchers have found no association between those variables (e.g., Schmidlin et al. 2008; Miran et al. 2018). The tornado's magnitude could impact this relationship (Afifi et al. 2014). Recent work by Demuth (2018) indicates that understanding past experiences with tornadoes as well as the impact of past experience on risk perception is complex. Demuth (2018) found four dimensions that characterize one's most memorable tornado experiences-risk awareness, risk personalization, personal intrusive impacts, and vicarious troubling impacts - and two constructs for those individuals with multiple experiences-common threat and impact communication 
as well as negative emotional responses. Relationships between these dimensions and risk perception vary statistically (some significant, some not), but Demuth (2018) calls for future research to more closely examine the impact of these new dimensions on risk perception. The roles of proximity and magnitude have also been associated with past tornado experiences and the ability to recall them in the future (Howe et al. 2014).

Reduced access to appropriate shelter options has led to reduced instances of safety planning and safe shelterseeking behavior (Balluz et al. 2000; Schultz et al. 2010). Similarly, individuals who reside in mobile or manufactured homes are more susceptible to injury and death during a tornado (Chaney and Weaver 2010; Chaney et al. 2013; Liu et al. 2019). The Southeast has more mobile home residents than any other part of the United States (MacTavish et al. 2006). Liu et al. (2019) found that mobile home residents in the Southeast "showed lower preparedness, lower self-efficacy to take shelter, lower access to shelter, and lower trust that the government will provide as much warning as possible about impending tornadoes" (paragraph 4). In the same study, about $50 \%$ of the mobile home participants indicated they would relocate to a vehicle for safety during a tornado warning instead of a stable building (Liu et al. 2019).

\section{e. Information sources: NWS personnel and their relationship with the public}

The NWS exists to "provide weather, water, and climate data, forecasts and warnings for the protection of life and property and enhancement of the national economy" (NOAA/NWS 2019a, paragraph 1). Forecasters and other NWS personnel have a responsibility to provide their knowledge to the public and thus are providing a daily service that can, at best, save people's lives (Fine 2007). Yet, they are often criticized by the public for forecasts that do not materialize, which can be draining (Fine 2007). For some forecasters, as Fine (2007) points out, they focus more on the scientific rather than the public part of the job: "...I think too often we forget what we are doing this for.....We get too fascinated by the meteorology....We don't think about who we are talking to and what the people want, and we never bother to ask" (p. 224). The responsibility of forecasters to translate esoteric weather data to everyday terms with a scientific backdrop for the public can be arduous (Daipha 2012). Illustrating a more complex process of warning the public of tornado threats, Nagele (2015) examines assessment and dissemination, with their respective subcomponents, and notes there are various actors besides NWS involved including local emergency management offices, local media, and fire and police departments (Nagele 2015). In addition to addressing immediate threats through scientific data, NWS also plays an important role in tornado harm prevention through education and outreach. Tornado warning safety protocol on various websites associated with NOAA/NWS is clear and consistent (e.g., https:// www.weather.gov/safety/tornado-during). It is important to note in this section that while NWS has considerable obligations to the safety of and interaction with the public, there is scant research regarding NWS personnel and their views on public response to tornado warnings (Sherman-Morris et al. 2018).

\section{Methods}

\section{a. Research participants and sampling}

The present qualitative study was part of a larger study to advance understanding of tornado warning response by residents in the southeastern United States, as well as perceptions of the NWS personnel who inform them. The specific geographic focus was three major cities in Tennessee-Knoxville, Memphis, and Nashville-and the 4 counties that included and surrounded each city, for 12 counties total.

To address this study's objectives, there were two types of participants: 1) forecasters from the National Weather Service locations in Tennessee; and 2) members of the public who are Tennessee residents. A purposive sample of forecasters $(n=11)$ was invited to participate-four from Morristown (near Knoxville), four from Memphis, and three from Nashville. The forecasters held varying roles such as Lead Forecaster, Senior Meteorologist, and Warning Coordination Meteorologist. The members of the public had previously participated in a survey that was part of the larger study and agreed to be contacted for a follow-up interview. The sample was narrowed to participants who completed the nighttime version of the survey (see Walters et al.2019) and tapered further to a subsample of individuals who, based on their survey responses, had low access, low knowledge, or an unsafe response to warnings.

Participants with low access were those who responded "no," "low," or "very low" chance when asked in the survey, "If there was a tornado warning during the [daytime/nighttime when most people are asleep], what are the chances you would find out about the warning?" (Mason et al. 2018). Participants with low knowledge were those whose response to the following open-ended question in the survey was incorrect: "In your own words, what does a tornado warning mean?" Mason et al. (2018, p. 564) describe the full coding process for these correct or incorrect responses. For a complete description of how participants were classified as having 
TABLE 2. Characteristics of general public vs all nighttime survey participants. This table provides and compares the characteristics of the general public participants $(n=45)$ with the full nighttime survey sample $(n=865)$ from which this study's public participants were selected.

\begin{tabular}{|c|c|c|}
\hline \multirow[b]{2}{*}{ Characteristic } & $\begin{array}{c}\text { General public } \\
\quad(n=45)\end{array}$ & $\begin{array}{l}\text { All nighttime } \\
\text { survey participants } \\
\quad(n=865)\end{array}$ \\
\hline & $\%$ or mean (range) & $\%$ or mean (range) \\
\hline Gender, female & 60.0 & 64.0 \\
\hline Age, years & $53.6(18,84)$ & $55.1(18,95)$ \\
\hline \multicolumn{3}{|l|}{ Education } \\
\hline High school or less & 36.4 & 27.2 \\
\hline $\begin{array}{l}\text { Some college or } \\
\text { technical/ } \\
\text { associates' degree }\end{array}$ & 25.0 & 36.0 \\
\hline $\begin{array}{l}\text { College degree } \\
\text { or more }\end{array}$ & 38.6 & 36.8 \\
\hline Lives in mobile home & 13.3 & 8.6 \\
\hline \multicolumn{3}{|l|}{$\begin{array}{l}\text { Tennessee region of } \\
\text { residence }\end{array}$} \\
\hline West & 35.6 & 32.7 \\
\hline Middle & 37.8 & 32.4 \\
\hline East & 26.7 & 34.9 \\
\hline
\end{tabular}

an unsafe response to warnings (i.e., not seeking shelter or seeking an inappropriate shelter), see Walters et al. (2019). In sum, participants were asked if they would take any of 12 different actions upon receiving a tornado warning ("do nothing, continue on as before", "contact family or friends," "seek shelter in your home," etc.). Their responses were then analyzed in conjunction with their housing type (e.g., someone in a mobile home should not seek shelter inside their home) to determine if the person indicated that they would make a safe choice, in line with NOAA recommendations for tornadic events that also consider housing type.

In the full nighttime survey, the percentage of respondents in each subsample category was $51.7 \%$ for low access, $27.6 \%$ for low knowledge, and $23.3 \%$ for unsafe response. Finally, a sample of those individuals from these subsample categories was drawn. Table 2 summarizes basic characteristics of these participants $(n=45)$ and compares them with the full sample of participants who completed the nighttime survey in the larger study.

\section{b. Data collection}

\section{1) NWS FORECASTER PARTICIPANTS}

The forecasters were interviewed for approximately one hour at their respective facilities about decisionmaking processes for tornado warnings during events of different convective modes and perceptions of the public. Interviewers used a semistructured topic guide that included many topics outside the scope of the present study (e.g., warning procedures; probability of detection, lead times, and false alarm rates; impact of seasonality and nocturnal events on procedures (Ellis et al. 2019a). For the present study, the NWS forecasters' perceptions of public response were explored through questions about how forecasters saw the reach and effectiveness of NWS messages, which groups of people seem more or less likely to seek safe shelter and why, and how else the public might be reached with tornado safety information. Follow-up questions to probe for depth and clarification were also used. Interviews were audio recorded and transcribed. Forecasters did not receive an incentive for their participation.

\section{2) General PUbliC PARTICIPANTS}

Semi-structured interviews were conducted via telephone with participants from the public and tended to last approximately $20 \mathrm{~min}$. A topic guide (Table 3 ) was used and included tornado warning access and response, preferences for tornado warning access and content, understanding of tornado warnings, and ideas for changes to tornado warnings or programmatic efforts. Interviews were audio recorded and transcribed. Participants were mailed a \$20 gift card for their assistance.

\section{3) DATA ANALYSIS AND INTERPRETATION}

Interview transcripts were coded by researchers using descriptive and interpretive coding (Creswell 2013; Tracy 2013). For the public interviews, a coding tree (available from the authors upon request) was constructed as several codes emerged, and this method helped organize codes into a digestible format for analysis. Thematic analysis was used to identify and interpret themes from the codes. Each set of interviews-general public and forecasters-was coded and interpreted by one researcher and verified by a second researcher. Any discrepancies were discussed and reconciled.

\section{Findings}

In this section, the results are organized to address each study objective, respectively.

a. Objective 1: To understand why some individuals have inadequate warning access, less understanding, and/or less likelihood of responding to tornado warnings in potentially harm-reducing or life-saving ways

\section{1) WARNING ACCESS}

The majority of participants identified one or more ways they might receive a tornado warning. Day or night, 
TABLE 3. Interview topic guide and sample questions used with general public participants. This table presents the topic guide used during interviews with general public participants, along with sample questions asked for each topic.

\begin{tabular}{|c|c|}
\hline Topic & Sample questions \\
\hline $\begin{array}{l}\text { How people receive tornado warnings, } \\
\text { during the daytime vs at night }\end{array}$ & $\begin{array}{l}\text { Have you ever gotten a tornado warning at night while sleeping before? } \\
\text { How have you gotten tornado warnings during the daytime? } \\
\text { How did you get the warnings? (e.g., text alert, tv, NOAA radio, etc.) }\end{array}$ \\
\hline $\begin{array}{l}\text { Individual choices in response to tornado } \\
\text { warnings, during the daytime vs at night }\end{array}$ & What did you do right after receiving the warning? Walk me through your response. \\
\hline $\begin{array}{l}\text { Explanations for individual choices (e.g., } \\
\text { why someone does or does not take } \\
\text { action upon receiving a tornado } \\
\text { watch/warning) }\end{array}$ & $\begin{array}{l}\text { Why do you think you chose to do } X \text { after you got the warning? } \\
\text { If you had it to do over again, would you change what you did? If so, how? } \\
\text { Is this how you usually respond or was there something different about this time? } \\
\text { In which situations, if any, do you usually move to a safe space? Why/why not? }\end{array}$ \\
\hline Understanding of tornado warnings & $\begin{array}{l}\text { Do you feel like you have enough knowledge about tornadoes and what to do if a } \\
\text { warning is issued? } \\
\text { If yes, how did you learn about tornadoes and what to do? } \\
\text { If no, what else would you like to learn? How would you like to learn this (i.e., what } \\
\text { ways of educating)? }\end{array}$ \\
\hline $\begin{array}{l}\text { Preferences or ideas for changes to } \\
\text { tornado warnings-or for } \\
\text { programmatic efforts-that will } \\
\text { improve tornado-related knowledge, } \\
\text { access, and behaviors }\end{array}$ & $\begin{array}{l}\text { How would you prefer to get warnings? } \\
\text { What information do you think a warning should include? } \\
\text { Do you have any suggestions about how the warning process could work better here } \\
\text { in Tennessee? }\end{array}$ \\
\hline
\end{tabular}

there was an overwhelming stated intention to collect more information about the storm rather than seek shelter immediately upon receipt. Many respondents stated that they turn on the television after receiving a cell phone warning to get confirmation. One respondent indicated they look at four to five channels to get enough information. Most believed that more detailed information is given in television reports. When asked how the information received in a cell phone warning differed from that received from television, a participant said, ". . . it [television] was more precise. It wasn't just a generalized you know tornado warning has been issued for your area." Other respondents said that cell phone warnings they received did not include a directive to take shelter immediately. While many knew about the FCC emergency alerts (WEAs), some were confused about how WEAs were sent, noting problems with setup despite them being an automatic feature if their carrier participates. Another important note is that only a few respondents mentioned social media as a way that they might get confirmation of a tornado.

Participants reported several other barriers to receiving tornado warnings. These include loss of power, rural locations, lack of storm radios, heavy sleep, and hearing impairments. There were numerous accounts of storm interference with normally available warning sources, such as cable television or internet access. One participant stated, "If we lose power, then we're out of luck. We do have a generator, but of course, I'm not going to go plug that up unless I'm without power for a long time, not just to listen to a storm." Another participant stated, "If I don't have the TV on, there ain't no warning around
here....It just hits." Some respondents had an alternate method to receive a warning, such as a weather radio or cell phone, but others did not. One pattern of response in those situations was to watch and listen to the storm and base their decision to take shelter on what they saw and heard:

“...most of us are looking at the TV. Of course, they've got it down to a science now. They can tell you within a block where it's at. So, now, if I didn't have that and I was outside, and I felt like the wind was getting stronger and stronger, then I would go to my safe place."

Another challenge was poor cell phone reception and the lack of internet or cable television due to rurality. One respondent stated, "...we live right here in the valley, you know, and like I said, you know, if they rely on internet. . . some places you can't even get internet."

NOAA weather radios were mentioned by several participants as a way to receive warnings upon losing power or reception. While interested in the devices, nearly none of the participants had a weather radio. Some indicated that it was a low priority, that they forget about it until a severe weather situation happens, or that the radios might be "annoying." However, most who considered owning a weather radio said that they could not afford to purchase one.

Regarding nighttime tornadoes, some respondents stated that they were heavy sleepers and have either not awoken to a cell phone warning in the past or were not confident that they would if one was sent. Those who have hearing issues may also have difficulty accessing a warning. One participant stated, “...my father-in-law...has 
you know, hearing loss and takes his hearing aids out at night." Another participant reported a similar situation with her father, though she stated that he wakes up when she calls him about the threat. Many individuals, especially those in rural areas, shared their desire for outdoor storm sirens to wake them while asleep, though they were unaware of a siren's intended use for warning individuals who are outdoors.

Several participants also reported seeking more information directly through their own senses by either looking or going outside or listening for wind, rain, and hail. One participant said, "I'm my own meteorologist" when discussing how they look at the clouds for changes. This behavior was professed even if the warning was received in the middle of the night. The sense used in nocturnal tornadic situations differed, however, as line of sight is hindered. In darkness, some respondents went outside and listened for cues that there might be a tornadic threat, for example, " ... everybody says it sounds like a train coming by, so you know, listen for the noise."

\section{2) RECEIVER KNOWLEDGE AND UNDERSTANDING} OF TORNADOES AND THEIR WARNINGS

Most participants indicated that they had sufficient knowledge about communication from NWS, specifically the difference between watches and warnings. Many shared that this information was imparted on them when they were children by their parents, educators when they were in school, or as adults by watching television. However, some participants did not have accurate knowledge of a tornado warning as demonstrated by one participant: "Well I always get confused. I'm thinking the warning is that conditions are favorable, and the watch is one's been. . . spotted. . . do I have it reversed?"

Several respondents indicated that tornadoes and their damaging effects should be taken seriously. Participants who resided in a single-family homes knew the recommended NWS behavioral response upon receiving a tornado warning: immediately take cover in a basement, storm cellar, or interior space in the lowest level of the structure; avoid doors and windows; and avoid taking shelter under overpasses or bridges when outdoors (NOAA/NWS 2019b; Edwards 2019). A few of these participants, though, noted unsafe responses during a tornado warning that are contraindicated by NWS, such as standing in a doorway or getting under an overpass if they were driving, because this is what they were taught to do by others (e.g., parents). For those residing in a mobile home, NOAA advises individuals to vacate the mobile home for a stable structure (NOAA/NWS 2019b). The six mobile home residents in this study all indicated unsafe responses to tornadoes in the full survey, and most verified unsafe behaviors in interviews such as taking cover in their bathrooms or hallways. Regardless of housing type and expressed knowledge of NWS safety protocol, the majority of respondents indicated that upon receiving a past tornado warning - or in a future event-they engaged or would engage in behaviors like going outside to look, staying in bed, sitting on the couch to watch television, or hiding out in a carwash.

Faulty thinking about tornadoes began to emerge with participants regarding the characteristics and behavior of tornadoes. A common myth observed in the data is a belief that topography is a protective factor against tornadoes. One participant stated,

"Every once in a while, one will get off and go somewhere it hadn't gone before, but most of the time they tend to have, if they get in past this ridge, they're going to stay on that side of that ridge. Or if they're from the middle, they're going to come down the middle."

Mountains, hills, valleys, and water were incorrectly cited as protective by some participants. One participant posited, "It's just a different climate here. When most severe storms hit the river, they seem to die down." Another mentioned that tornadoes near their location usually went north or south, so they are not likely to hit their home.

\section{3) RECEIVER CHARACTERISTICS IMPACTING LIKELIHOOD OF SEEKING SHELTER IN A TORNADO WARNING}

This subsection addresses characteristics of individuals that may impact their actions upon receiving a tornado warning. These include how far they were from a tornado (proximity); if they had personal experiences with tornadoes in the past; and if they had family or friends.

In addition to explicit direction, participants noted proximity of the reported tornado as an issue affecting their decision-making, such as the following:

"... I know they want to be short, but at least it could be explained a little bit more. Like if they need to tell me take shelter now, okay. Or if it says there's a tornado in your area, you know, that's too general. So, 'in my area' could be 50 miles away, and I'm like, oh, that's not close. How close it is in terms of enough time to take action would be useful."

Numerous respondents described their counties as quite large and stated that warnings often cover entire counties. Therefore, hearing that a tornado has touched down or been sighted within county lines is not enough to instigate immediate sheltering action. When asked 
how close a tornado sighting would need to be to take shelter, one person stated, "Probably a couple of miles." One participant said she would seek shelter if the tornado were within 50 miles of her house, while another participant said it would have to be within 10 miles.

While having a personal experience with a tornado influenced some people to become more cautious, for others it had the opposite effect. One of the respondents witnessed a tornado as a child but still felt that "... it would never happen to me." In fact, she had another encounter with a tornado, and this time she was outside and had to hold onto a pillar to keep from getting swept up into it. She said, "Watching it is one thing. Being in it is totally different. And you know, I guess because I had the comfort of my grandmother or somebody there with me that I just knew would handle things. They would keep us safe." Another stated:

“There's so many things that happen that don't necessarily happen, tornado warnings for instance, don't necessarily happen. They've never hit me. So, I don't jump up and run into a closet or whatever every time I hear one. I guess if that ever happened to me personally, I probably would."

The influence of family and friends emerged as a theme. Several respondents shared that, as part of their response to warnings, they call or text their family members and friends to either get more information or to inform them of an impending storm. Some said they might check on elderly or disabled neighbors. A few respondents indicated that while they cared about protecting their families in the past, they would not take protective actions because they now lived alone and did not care about their personal well-being. Another impact of family involved knowledge attainment. Some parents and grandparents who were interviewed stated that they were open to receiving education second-hand through their children who could gain knowledge about tornadoes and protective actions at school. One person said, “. ..that's how I keep getting refreshed because [my children] come home and tell me what they've learned."

\section{b. Objective 2: Examine public attitudes and opinions} about NWS communications and how these could improve

\section{ATTITUDES ABOUT NWS COMMUNICATIONS}

Many respondents indicated satisfaction with the NWS and its warning systems, and that false alarms did not impact their response to tornado warnings. A few positively mentioned their local television weathercasters by name, indicating trust in their reports. Yet, there were some who stated that false alarms made them rethink their actions: "I think they would probably have to be, um, just say careful because they, you don't want to create hysteria because then it's like the boy who cried wolf and it's like, 'Oh, that didn't work," the participant shared.

Most respondents initially did not have suggestions for changes in the process. Nonetheless, several respondents voiced a desire for more specific information in cell phone warnings based on their location and were open to receiving more or different alarm notifications in the event of a threat. Knowing the proximity of the threat and time of arrival in their location was clearly important to many participants. One participant expressed appreciation for location information included in warnings that she receives via an application downloaded on her cell phone. She stated, “. . . it would say it was detected within so many miles, um from where I'm at. . . Since I've gotten this, I feel like I'm more notified of it more than ever.', Some respondents report having access to this level of detail in warnings, while others do not. Another participant idea was to put a link into the warnings to allow people to gather more information on their phone if they wanted it - though this is prohibited by the FCC. Many explicitly desired more storm sirens in their areas.

\section{c. Objective 3: Explore the perceptions of NWS personnel regarding the public's behavioral response to tornado warnings, factors that might influence public response, and how their perceptions of the public's response impact their communication regarding warnings}

\section{1) NWS PERCEPTIONS OF PUBLIC RESPONSE TO WARNINGS AND FACTORS THAT INFLUENCE RESPONSE}

A common perception among NWS personnel was that many people receive a warning, but they want confirmation (e.g., going outside to check the weather, personally seeing or hearing severe weather) before heeding a warning. They perceive that confusion and doubt can arise when message recipients cannot see severe weather, or it is not actually impacting their part of the county. Proximity, according to several NWS personnel, matters a great deal to the recipients of warnings. Thus, some personnel concurred that if the tornado is not going to hit someone's house or neighborhood, some people do not want to be bothered with reports.

Some population groups were perceived by NWS personnel to react less appropriately than others 
when tornado warnings are issued. One NWS participant believed younger individuals, specifically those with no tornado experience, were more interested in chasing extreme weather for excitement rather than seeking shelter. A few NWS personnel considered challenges with Hispanic individuals or people not fluent in English, fearing they might not comprehend or have access to tornado warnings. Economically disadvantaged people were referenced a few times as a group who might not be seeking shelter, though the reasons why some NWS personnel were concerned about this group were unclear. Most NWS participants also expressed concern that residents of the Southeast have poor access to safe shelters, in general. One forecaster recalled an EF5 event:

"Could it have just been it was an EF5 tornado going through a populated area on a Sunday when most everybody was at home? Could that also be why people died? I mean, did everybody that died blatantly ignore the warnings? Probably not. They probably didn't have adequate shelter for an EF5 going through a metro city... . So, I hated that the service assessment completely blamed sirens for that. I feel like the issue needs to be addressed more of the adequate shelters in the southeast that are just not found."

Mobile home residents were mentioned several times as particularly vulnerable to harm during tornadoes. Public shelters in Tennessee, according to the NWS participants, are rare, and they recommended that people identify family, friends, or neighbors who are close by and shelter with them. A few NWS personnel elaborated by stating that residents should go to these locations upon receiving a tornado watch and not wait for a tornado warning to be issued.

Some NWS personnel surmised that experience with destructive tornadoes impacted decisions to seek shelter. NWS participants explained that individuals are more likely to take tornado warnings seriously and react appropriately when they have experienced a "big event" or "outbreak" and they or people known to them get hurt or have property damage. One NWS employee shared their confidence in the region's understanding of a tornado's potential for destruction due to a massive event that occurred 30 years ago, while another forecaster thought that once time had passed, the impression of the event was lost and did not contribute to one's decision to seek shelter. Some NWS personnel indicated that experience with false alarms might contribute to individuals not seeking shelter during a tornado: "...people kind of get immune to it. They'll say, 'Well, all these times in my life, I've been warned for a tornado, but I've never seen one.' So, I wonder sometimes if people are just, 'Oh, just another tornado warning.",

Trust in the deliverer of the warning was also perceived as a factor that contributed to people's response (or lack thereof). NWS personnel reflected that confidence in forecasters may encourage the public to believe warnings and then seek appropriate shelter. However, overcoming distrust and increasing credibility are challenging:

"How do I communicate that in a way that doesn't make me less credible as a source of information? Because you always get the, 'As a part of being a meteorologist, you get paid to be wrong $90 \%$ of the time.' I think that's actually the opposite. We are right $90 \%$ of the time at least..."

Forecasters believed that a part of the public does not care about or is not interested in weather, including tornadoes. They suggested that lack of interest or concern could be related to their place of residence (e.g., rural versus urban). Rural residents were perceived by NWS personnel as more interested in weather and more prepared to seek shelter:

"...there is a huge difference between those that are in the metro area versus rural... . Whether it's local TV media, meteorologists telling them to take cover. . I feel as though, in rural communities, they're going to follow through with that....they're going to do the best that they can."

Another NWS employee shared that lack of interest could be a pattern of behavior continuing from childhood and some people have yet to find value in weather reports. Moreover, some NWS personnel noted that individuals who are not informed or "weather savvy" might be distracted by other priorities, like entertainment:

“...there's people who, during a basketball game or a sporting event or their favorite TV show, 'Don't you dare interrupt with the crawler, or don't you go wall to wall. How dare you go wall to wall during my favorite show? You're stupid.' TV mets [meteorologists] have to deal with that all the time. We get phone calls for the emergency alert system going off. 'You're interrupting my news'..."

Meanwhile, another NWS participant remarked that poor response to tornado warnings could also stem from fascination with tornadoes: While often devastating and scary, tornadic events are mystifying, and thus, people want to observe them first-hand rather than take cover.

Fatalistic thinking was mentioned by a few NWS participants, which is the idea that proactive behavior and protective actions are useless because destiny is predetermined: “... 'if it's my time, then it's my time."” The NWS personnel who identified this factor as a reason for people not seeking shelter upon receiving a 
tornado warning connected this rationale to religion, older age, lack of a support system, and having low income. Similarly, several NWS personnel perceived that some people are simply complacent, as in ". . if it happens, it's going to happen to somebody else, it's not going to happen to me." A few NWS participants shared that members of the public with inaccurate knowledge related to geography was problematic: individuals might believe that mountains protect their areas and limit the number of tornadic events.

Regarding access, NWS personnel believe that the public receiving tornado warnings continues to be a problem. One forecaster mentioned a specific concern for the elderly population as they may not have as many options to receive NWS messages. Yet, some people, they believe, do not receive warnings because they turn off weather radios or televisions because the interruptions from the NWS are inconvenient and intrusive, or because many people no longer use radios or local television for everyday entertainment. Overall, though, forecasters shared that social media and other technology have significantly increased the connection between the NWS and the public, leading to positive interactions and better-informed individuals. However, some forecasters indicated that using technology (e.g., smartphone apps and social media) can cause people to miss tornado warnings if, for example, they go to bed before the warning is issued, and they do not have a weather radio to provide notifications. Two participants shared that various weather apps and websites have led to a saturation of information related to weather, making some people question who to trust and where to get information first.

Even when received, accurate translation of the warning is dependent upon the recipient's knowledge of NWS messages. One forecaster shared an experience of a woman confusing a warning with a watch, who said there was "nothing to worry about" in connection with an issued tornado warning. Education about warnings versus watches, as a few NWS participants noted, is critical because there are still people who do not know the difference.

\section{2) HOW PERCEPTIONS IMPACT THEIR COMMUNICATIONS}

NWS personnel described a constant struggle among themselves to determine how to word warnings that will motivate people to seek shelter immediately and every time a warning is issued. It was clear that several NWS participants were troubled by members of the public not seeking shelter upon receiving a warning and instead engaging in other actions (e.g., going outside, looking for information on multiple sources). One NWS personnel shared, "Especially if it's in the middle of the night, just go to your shelter first and then deem necessary, figure out whether or not you can come out of it." Therefore, "call to actions" and urgency and tone of the warnings were regarded as necessary by some NWS participants. One forecaster noted:

“They've never been in that situation before and that's what I want to try and learn about. How can I take that warning and make them take it seriously? Understand that their life is significantly more at risk now versus an hour ago, of like $99.9 \%$ of the days they've lived there."

Another forecaster suggested that specificity in warnings (e.g., northern part of the county) is also important so that recipients will believe and act on warnings without hesitation. Nonetheless, immediacy is a genuine issue for NWS personnel, and thus, changing the warning message with each tornadic event is not practical: "Do we use the same phraseology over and over and over again? Maybe. But if we don't, it's going to take too long and type it up and send it, it's already done."

One public factor that seemed to impact NWS personnel actions substantially was adequate shelter during tornado warnings-specifically, among mobile home residents. Regarding an active storm night, one NWS participant shared:

“. . .if it's a storm at night, there's canned statement for tornadoes that are especially dangerous at night. If it's in a rural area where I know there's a lot of mobile homes, I really try to hit that one since, I think it's roughly $60 \%$ of our fatalities from our county warning area are mobile home fatalities unfortunately. That's pretty cognizant wherever you go I think, but that's what I'm trying to think about as a forecaster. There's just so many positions now in the weather service in the severe weather operations that go far beyond just issuing a warning."

Another forecaster said that he often thinks of mobile home residents when disseminating forecasts and conducting spotter trainings: "I always tell the folks that have mobile homes, it's when the watch has just first been issued that you need to leave your location and go to an alternate shelter.' Further, other NWS personnel concurred that vacating mobile homes preemptively was a message they tried to reiterate to the public.

\section{Discussion}

This study used a qualitative approach with semistructured interviews to gain a deeper understanding of Tennessee residents - a proxy for the Southeastern region-who had low access, low knowledge, or an unsafe 
response to tornado warnings. While many quantitative studies have been conducted on these topics, fewer researchers employ qualitative methods, which ultimately allowed us to uncover rich data. This study thus directly addresses some of NWS personnel's lingering questions and charges for research as outlined by Sherman-Morris et al. (2018). Additionally, we sought the perspectives of Tennessee NWS personnel regarding public response, factors that influence response, and how these perspectives of the public impact their communications. This objective was significant because NWS personnel are not often studied though they are highly responsible to and connected with the public.

\section{a. Access and subsequent response}

There is a noticeable disconnect between the rhetoric of NWS personnel in this study regarding seeking shelter immediately and the public's preference for additional information. NWS personnel emphasized their concern for the public internalizing risk of tornadoes immediately upon receiving warnings. Public participants in our sample generally noted that they take severe weather and warnings seriously in that they believe these events can be destructive and therefore will seek out additional information. However, the act of taking cover as suggested by NWS is one step that many public participants were not willing to take unless they had visual confirmation based on environmental cues or were certain-based on information they gathered from multiple sources-that the tornado was close enough in terms of proximity to cause damage. Mileti and Sorensen (1990) theorize that understanding (attaching meaning), believing (deciding legitimacy), and personalizing (determining if they threat impacts them) are stages that a person might pass through before ultimately deciding how to react to a threat like a tornado warning-obtaining information from multiple sources plays into these stages. Yet, NWS safety protocols (e.g., https://www.weather.gov/safety/tornado-during) suggest that waiting until this point is often too late, putting individuals at risk for injury or death. Like past research (Nagele and Trainor 2012), there is public uncertainty around threat and proximity. Proximity was not defined in our study, and when the topic arose, participants had various definitions about how close was close enough to seek shelter (i.e., a few miles, $10 \mathrm{mi}, 50 \mathrm{mi}$ ). NWS might consider how to define proximity in a digestible way for the public since this is a factor that many contemplate-is this tornado close enough to where I am to impact my wellbeing? Education about this topic and subsequent alerts that emphasize proximity may assist with personalizing the threat, reduce the need for additional confirmations, and decrease the amount of time it takes for people to seek shelter.

\section{b. Receiver knowledge and understanding of tornadoes and their warnings}

Comprehension of tornado warnings by the general public was a matter of interest for the NWS forecasters in this study, which is consistent with Sherman-Morris et al. (2018). They believed that, despite education efforts, there are people who do not have a basic understanding of tornadoes and warnings. This conclusion proved to be true among some of our public participants, who were selected in part for their low warning knowledge. Indeed, some people were not certain about the differences between a watch and warning as well as those who shared unsafe response behaviors (i.e., stand in a doorway). Parallel to existing research (e.g., Donner et al. 2012; Ellis et al. 2019b; Klockow et al. 2014), myths about tornadoes and their behavior also emerged in our data. Therefore, regular community education is still a necessary activity for the NWS. Some of our participants noted that they learned or refreshed their tornado knowledge from children because of lessons occurring in schools; accordingly, outreach to local school districts might be effective. Providing flyers with basic information, tips, and resources may be a good investment and serve as conversation starters within families. Also, because many people continue to get their weather information from television, encouraging local meteorologists to provide regular education is important. At the same time, with social media and smartphone use on the rise, online engagement cannot be forgotten or underestimated. Additional education regarding WEAs should also be considered as many of our participants were unaware of how this process worked.

\section{c. Receiver characteristics and subsequent response}

Another concern of NWS personnel was the elderly's ability to receive warnings, and a few respondents from the general public reciprocated this fear, particularly at night when they may not hear cell phone alerts. Yet, overall, participants in our sample were older, and interviewers talked with elderly individuals who indicated having access and seeking warnings through television. Still, as some general public participants did, NWS may consider encouraging people to check on their elderly family and neighbors, as well as non-English speaking individuals or those unfamiliar with tornadoes, in the case of a serious storm. NWS personnel also discussed relying on family and friends for those individuals who are residing in mobile homes or other shelters deemed unsafe during a tornado. Family and friend investment into the warning process proved to be important in our 
study as well as others (e.g., Burke et al. 2012; Durage et al. 2014; Walters et al. 2019). Because family and friends might influence behavior, NWS should consider a special campaign geared toward mobile home-dense areas that encourages family and friends (as part of their preparedness plans) to reach out to or visit mobile home residents to inform them about impending severe weather and discuss safe shelter options.

Forecasters tended to express concern about urban residents being less likely to follow weather or heed warnings, than rural residents. However, rural residents are a segment of the population that may need more attention. Due to lack of quality internet and television signals, people in rural areas may not have access to backup information sources if their electricity goes off. In geographic areas where access may be an issue, warning as far in advance as possible and imparting that a potential risk for severe weather days prior might help them prepare. Encouraging the purchase of NOAA radios to use a backup option may be important as well.

Individuals with lower incomes were a concern for NWS personnel, likely due to lower access to information and adequate shelter. With the public participants, money - or lack thereof-arose in the discussion relating to NOAA radios. While a few participants said NOAA radios were "annoying" and that they might turn them off, many people indicated their interest in having a weather radio but said that they were unable to afford one. This finding might indicate individuals are unaware of the current price points of NOAA radios with some as low as $\$ 15$. Or, indeed, $\$ 15$ may be too much for people who have a lower socioeconomic status. Nonetheless, the NWS might consider, especially in rural areas and with the elderly, ways to get these devices to people to increase reliable access to warnings and then train them on how to use them properly. This might be a good alternative to installing more sirens, which was desired by many public participants who were unaware of their intended purpose of outdoor notification.

\section{d. NWS communications with the public}

NWS personnel questioned the public's trust in them and their products. However, the public participants respected and expressed good faith in NWS and their work. Despite having false alarms in their areas, most participants indicated that these did not impact their future response. Also, many people did not have suggestions on how to improve the warning process, other than geographic specificity. While continuing outreach and education efforts, the NWS might consider the issues related to messaging, particularly proximity and direct language.

\section{Conclusions}

This study addressed many of the concerns from NWS personnel identified by Sherman Morris et al. (2018), including warning information wanted by the public, the level of understanding around NWS products, and behaviors taken upon receiving a warning. The study further addressed the lack of NWS personnel perspectives available in current literature. Our findings revealed that NWS personnel held some attitudes and concerns that paralleled with the public responses, though other themes surfaced that diverged. Calling on the process of Mileti and Sorensen (1990), the most prominent divergent theme is that while the public hears and understands the warning, they may not believe or personalize the risk enough to seek shelter immediately upon receiving a warning, which is the recommendation of NWS. Instead, they seek out additional information and multiple confirmations. The authors acknowledge that one of the key limitations of the study is the few mobile home residents who participated in the study. Their perspective is valuable as adequate shelter is pivotal in reducing injury and fatality, as noted by the NWS personnel in this study. It is also important to acknowledge that this research was conducted in one state, and thus, similar research in other Southeast states is necessary to uncover further insight into the topics of access, knowledge, and response from the perspectives of the public and NWS personnel in an effort to save lives. Specific research needs arising from this study include the inclusion of proximity in warning messages and the impact on shelter-seeking behavior, mobile home residents' use of family and friends for adequate shelter, and access and use of NOAA radios in rural areas.

Acknowledgments. This study was funded by the National Oceanic and Atmospheric Administration (NA15OAR4590225, NA16OAR4590222). The authors thank the anonymous reviewers of this article who provided valuable insight to enhance the quality of the content.

\section{REFERENCES}

Afifi, W., T. Afifi, and A. Merrill, 2014: Uncertainty and control in the context of a category-five tornado. Res. Nurs. Health, 37, 358-366, https://doi.org/10.1002/nur.21613.

Agee, E., and L. Taylor, 2019: Historical analysis of U.S. tornado fatalities (1808-2017): Population, science and technology. Wea. Climate Soc., 11, 355-368, https://doi.org/10.1175/wcas-d-18-0078.1

Ahlborn, L., and J. Franc, 2012: Tornado hazard communication disparities among Spanish-speaking individuals in an Englishspeaking community. Prehosp. Disaster Med., 27, 98-102, https://doi.org/10.1017/S1049023X12000015. 
Ajzen, I., and M. Fishbein, 2005: The influence of attitudes on behavior. The Handbook of Attitudes, D. Albarracín, B. T. Johnson, and M. P. Zanna, Eds., Lawrence Erlbaum, 173-221.

Ash, K., 2017: A qualitative study of mobile home resident perspectives on tornadoes and tornado protective actions in South Carolina, USA. GeoJournal, 82, 533-552, https:// doi.org/10.1007/s10708-016-9700-8.

Ashley, W. S., 2007: Spatial and temporal analysis of tornado fatalities in the United States: 1880-2005. Wea. Forecasting, 22, 1214-1228, https://doi.org/10.1175/2007WAF2007004.1.

_ A. J. Krmenec, and R. Schwantes, 2008: Vulnerability due to nocturnal tornadoes. Wea. Forecasting, 23 (5), 795-807, https:// doi.org/10.1175/2008WAF2222132.1.

Balluz, L., L. Schieve, T. Holmes, S. Kiezak, and J. Malilay, 2000: Predictors for people's response to a tornado warning: Arkansas, 1 March 1997. Disasters, 24, 71-77, https://doi.org/ 10.1111/1467-7717.00132.

Blanchard-Boehm, R. D., and M. J. Cook, 2004: Risk communication and public education in Edmonton, Alberta, Canada on the 10th anniversary of the 'Black Friday' tornado. Int. Res. Geogr. Environ. Educ., 13, 38-54, https://doi.org/10.1080/10382040408668791.

Brotzge, J., and W. Donner, 2013: The tornado warning process: A review of current research, challenges, and opportunities. Bull. Amer. Meteor. Soc., 94, 1715-1733, https://doi.org/ 10.1175/BAMS-D-12-00147.1.

Burke, S., J. Bethel, and A. F. Britt, 2012: Assessing disaster preparedness among Latino migrant and seasonal farmworkers in Eastern North Carolina. Int. J. Environ. Res. Public Health, 9, 3115-3133, https://doi.org/10.3390/ijerph9093115.

Chaney, P., and G. Weaver, 2010: The vulnerability of mobile home residents in tornado disasters: The 2008 Super Tuesday tornado in Macon County, Tennessee. Wea. Climate Soc., 2, 190-199, https://doi.org/10.1175/2010WCAS1042.1.

,,-- S. Youngblood, and K. Pitts, 2013: Household preparedness for tornado hazards: The 2011 disaster in DeKalb County, Alabama. Wea. Climate Soc., 5, 345-358, https:// doi.org/10.1175/WCAS-D-12-00046.1.

Chiu, C. H., A. H. Schnall, C. E. Mertzlufft, R. S. Noe, A. F. Wolkin, J. Spears, M. Casey-Lockyer, and S. J. Vagi, 2013: Mortality from a tornado outbreak, Alabama, April 27, 2011. Amer. J. Public Health, 103, e52-e58, https://doi.org/10.2105/ AJPH.2013.301291.

Coleman, T. A., and P. G. Dixon, 2014: An objective analysis of tornado risk in the United States. Wea. Forecasting, 29, 366376, https://doi.org/10.1175/WAF-D-13-00057.1.

Comstock, R., and S. Mallonee, 2005: Comparing reactions to two severe tornadoes in one Oklahoma community. Disasters, 29, 277-287, https://doi.org/10.1111/j.0361-3666.2005.00291.x.

Cong, Z., D. Liang, and J. Luo, 2014: Family emergency preparedness plans in severe ornadoes. Amer. J. Prev. Med., 46, 89-93, https://doi.org/10.1016/j.amepre.2013.08.020.

Creswell, J. W., 2013: Qualitative Inquiry and Research Design: Choosing among Five Approaches. Sage, 474 pp.

Daipha, P., 2012: Weathering risk: Uncertainty, weather forecasting, and expertise. Sociol. Compass, 6, 15-25, https://doi.org/ 10.1111/j.1751-9020.2011.00437.x.

Demuth, J. L., 2018: Explicating experience: Development of a valid scale of past hazard experience for tornadoes. Risk Anal., 38, 1921-1943, https://doi.org/10.1111/risa.12983.

Donner, W., H. Rodriguez, and W. Diaz, 2012: Tornado warnings in three southern states: A qualitative analysis of public response patterns. J. Homeland Secur. Emerg. Manage., 9 (2), https://doi.org/10.1515/1547-7355.1955.
Durage, S., L. Kattan, S. Wirasinghe, and J. Ruwanpura, 2014: Evacuation behaviour of households and drivers during a tornado. Nat. Hazards, 71, 1495-1517, https://doi.org/10.1007/ s11069-013-0958-6.

Edwards, R., 2019: Tornado safety. NOAA, accessed 10 March 2019, https://www.spc.noaa.gov/faq/tornado/safety.html.

Ellis, K., D. Burow, K. Gassert, L. Mason, and M. Porter, 2019a: Forecaster perceptions and climatological analysis of the influence of convective mode on tornado climatology and warning success. Ann. Amer. Assoc. Geogr., https://doi.org/ $10.1080 / 24694452.2019 .1670042$, in press.

__ L. Mason, and K. Gassert, 2019b: Public understanding of local tornado characteristics and perceived protection from land-surface features in Tennessee, USA. PLoS One, 14, e0219897, https://doi.org/10.1371/journal.pone.0219897.

Federal Communications Commission, 2018: Wireless emergency alerts (WEA). FCC, accessed 15 March 2019, https://www. fcc.gov/consumers/guides/wireless-emergency-alerts-wea.

Fine, G. A., 2007: Authors of the Storm: Meteorologists and the Culture of Prediction. University of Chicago Press, $280 \mathrm{pp}$.

Fricker, T., J. B. Elsner, V. Mesev, and T. H. Jagger, 2017: A dasymetric method to spatially apportion tornado casualty counts. Geomatics Nat. Hazards Risk, 8, 1768-1782, https:// doi.org/10.1080/19475705.2017.1386724.

Hammer, B., and T. Schmidlin, 2002: Response to warnings during the 3 May 1999 Oklahoma City tornado: Reasons and relative injury rates. Wea. Forecasting, 17, 577-581, https://doi.org/ 10.1175/1520-0434(2002)017<0577:RTWDTM > 2.0.CO;2.

Howe, P. D., H. Boudet, A. Leiserowitz, and E. W. Maibach, 2014: Mapping the shadow of experience of extreme weather events. Climatic Change, 127, 381-389, https://doi.org/10.1007/ s10584-014-1253-6.

Ingram, K., K. Dow, L. Carter, and J. Anderson, 2013: Climate of the Southeast United States: Variability, Change, Impacts, and Vulnerability. Island Press, $252 \mathrm{pp}$.

Jauernic, S., and M. Van Den Broeke, 2016: Perceptions of tornadoes, tornado risk, and tornado safety actions and their effects on warning response among Nebraska undergraduates. Nat. Hazards, 80, 329-350, https://doi.org/10.1007/s11069-0151970-9.

— , and — 2017: Tornado warning response and perceptions among undergraduates in Nebraska. Wea. Climate Soc., 9, 125-139, https://doi.org/10.1175/WCAS-D-16-0031.1.

Klockow, K., E. Peppler, and R. McPherson, 2014: Tornado folk science in Alabama and Mississippi in the 27 April 2011 tornado outbreak. GeoJournal, 79, 791-804, https://doi.org/ 10.1007/s10708-013-9518-6.

Lindell, M. K., and R. W. Perry, 2012: The protective action decision model: Theoretical modifications and additional evidence. Risk Anal., 32, 616-632, https://doi.org/10.1111/ j.1539-6924.2011.01647.x.

, and H. Brooks, 2013: Workshop on Weather Ready Nation: Science imperatives for severe thunderstorm research. Bull. Amer. Meteor. Soc., 94, ES171-ES174, https://doi.org/10.1175/ BAMS-D-12-00238.1.

Liu, B., M. Egnoto, and J. Lim, 2019: How mobile home residents understand and respond to tornado warnings. Wea. Climate Soc., 11, 521-534, https://doi.org/10.1175/WCAS-D-17-0080.1.

Liu, S., L. Quenemoen, J. Malilay, E. Noji, T. Sinks, and J. Mendlein, 1996: Assessment of a severe-weather warning system and disaster preparedness, Calhoun County, Alabama, 1994. Amer. J. Public Health, 86, 87-89, https://doi.org/ 10.2105/AJPH.86.1.87. 
Losee, J. E., and S. Joslyn, 2018: The need to trust: How features of the forecasted weather influence forecast trust. Int. J. Disaster Risk Reduct., 30, 95-104, https://doi.org/10.1016/ j.ijdrr.2018.02.032.

Luo, J., Z. Cong, and D. Liang, 2015: Number of warning information sources and decision making during tornadoes. Amer. J. Prev. Med., 48, 334-337, https://doi.org/10.1016/ j.amepre.2014.09.007.

MacTavish, K., M. Eley, and S. Salamon, 2006: Housing vulnerability among rural trailer-park households. Georgetown J. Poverty Law \& Policy, 13, 95-118.

Mason, L. R., K. N. Ellis, B. Winchester, and S. Schexnayder, 2018: Tornado warnings at night: Who gets the message? Wea. Climate Soc., 10, 561-568, https://doi.org/10.1175/wcas-d-17-0114.1.

Mileti, D. S., and J. H. Sorensen, 1990: Communication of emergency public warnings: A social science perspective and state-of-the-art assessment. U.S. Dept. of Energy, Office of Scientific and Technical Information, accessed 8 August 2019, https://doi.org/10.2172/6137387.

Miran, S. M., C. Ling, and L. Rothfusz, 2018: Factors influencing people's decision-making during three consecutive tornado events. Int. J. Disaster Risk Reduct., 28, 150-157, https:// doi.org/10.1016/j.ijdrr.2018.02.034.

Nagele, D., 2015: Evolution of culture among warning system organizations. Ph.D. dissertation, University of Delaware, $262 \mathrm{pp}$.

— and protective action. Wea. Climate Soc., 4, 145-155, https:// doi.org/10.1175/WCAS-D-11-00047.1.

NOAA/NWS, 2011a: Service assessment: The historic tornadoes of April 2011. NOAA, 76 pp., https://www.weather.gov/ media/publications/assessments/historic_tornadoes.pdf.

—_ 2011b: NWS Central Region service assessment: Joplin, Missouri, tornado-May 22, 2011. NOAA, 41 pp., https://www.weather.gov/ media/publications/assessments/Joplin_tornado.pdf.

_ 2011c: National Weather Service Birmingham AL reduced tornado warning false alarm rate by $31 \%$ since April 2011. NOAA, accessed 10 March 2019, https://www.weather.gov/ bmx/research_falsealarms.

_ 2019a: About the NWS. NOAA, accessed 15 March 2019, https://www.weather.gov/about/.

— , 2019b: Tornado safety. NOAA, accessed 15 March 2019, https://www.weather.gov/safety/tornado.

- 2019c: National Weather Service preliminary damage assessment report for the March 32019 tornado outbreak. NOAA, accessed 10 March 2019, https://mesonet.agron.iastate.edu/wx/ afos/p.php? pil $=$ PNSFFC\&e $=201903071739$.

NOAA/SPC, 2018a: Severe weather database files (1950-2017). NOAA, accessed 8 August 2019, https://www.spc.noaa.gov/wcm/\#data.

_ 2018b: Tornado-related fatality information. NOAA, accessed 8 August 2019, https://www.spc.noaa.gov/climo/online/\#deadly.

Paul, B., M. Stimers, and M. Caldas, 2015: Predictors of compliance with tornado warnings issued in Joplin, Missouri, in 2011. Disasters, 39, 108-124, https://doi.org/10.1111/disa.12087.

Pew Research Center, 2018: Mobile fact sheet. Accessed 15 March 2019, https://www.pewinternet.org/fact-sheet/mobile/.
Rasmussen, E., 2015: VORTEX-Southeast program overview. NOAA, accessed 8 August 2019, ftp://ftp.atdd.noaa.gov/pub/ vortexse/ProjectOverview.pdf.

Ripberger, J., C. Silva, H. Jenkins-Smith, and M. James, 2015: The influence of consequence-based messages on public responses to tornado warnings. Bull. Amer. Meteor. Soc., 96, 577-590, https://doi.org/10.1175/BAMS-D-13-00213.1.

Schmidlin, T., B. Hammer, Y. Ono, and P. King, 2008: Tornado shelter-seeking behavior and tornado shelter options among mobile home residents in the United States. Nat. Hazards, $\mathbf{4 8 ,}$ 191-201, https://doi.org/10.1007/s11069-008-9257-z.

Schultz, D. M., E. C. Gruntfest, M. H. Hayden, C. C. Benight, S. Drobot, and L. R. Barnes, 2010: Decision making by Austin, Texas, residents in hypothetical tornado scenarios. Wea. Climate Soc., 2, 249-254, https://doi.org/10.1175/ 2010wcas1067.1.

Senkbeil, J., M. Rockman, and J. Mason, 2012: Shelter seeking plans of Tuscaloosa residents for a future tornado event. Wea. Climate Soc., 4, 159-171, https://doi.org/10.1175/WCAS-D-11-00048.1.

Sherman-Morris, K., 2005: Tornadoes, television and trust-A closer look at the influence of the local weathercaster during severe weather. Environ. Hazards, 6, 201-210, https://doi.org/ 10.1016/j.hazards.2006.10.002.

, 2010: Tornado warning dissemination and response at a university campus. Nat. Hazards, 52, 623-638, https://doi.org/ 10.1007/s11069-009-9405-0.

, H. Lussenden, A. Kent, and C. MacDonald, 2018: Perceptions about social science among NWS warning coordination meteorologists. Wea. Climate Soc., 10, 597-612, https://doi.org/10.1175/ wcas-d-17-0079.1.

Silver, A., 2015: Watch or warning? Perceptions, preferences, and usage of forecast information by members of the Canadian public. Meteor. Appl., 22, 248-255, https://doi.org/10.1002/met.1452.

perience and sociodemographics on protective behaviors during two successive tornado events. Wea. Climate Soc., 6 , 91-103, https://doi.org/10.1175/WCAS-D-13-00026.1.

Simmons, K. M. and D. Sutter, 2009: False alarms, tornado warnings, and tornado casualties. Wea. Climate Soc., 1, 38-53, https://doi.org/10.1175/2009WCAS1005.1.

Tracy, S. J., 2013: Qualitative Research Methods: Collecting Evidence, Crafting Analysis, Communicating Impact. Wiley Blackwell, 632 pp.

Trainor, J. E., D. Nagele, B. Philips, and B. Scott, 2015: Tornadoes, social science, and the false alarm effect. Wea. Climate Soc., 7, 333-352, https://doi.org/10.1175/WCAS-D-14-00052.1.

Van Den Broeke, M. S., and L. Arthurs, 2015: Conceptions of tornado wind speed and land surface interactions among undergraduate students in Nebraska. J. Geos. Educ., 63, 323-331, https://doi.org/10.5408/14-029.1.

Walters, J. E., L. R. Mason, and K. N. Ellis, 2019: Examining patterns of intended response to tornado warnings among residents of Tennessee, United States, through a latent class analysis approach. Int. J. Disaster Risk Reduct., 34, 375-386, https://doi.org/10.1016/j.ijdrr.2018.12.007. 